\title{
Terminal Sterilization
}

National Cancer Institute

\section{Source}

National Cancer Institute. Terminal Sterilization. NCI Thesaurus. Code C113071.

Sterilization of a finished product. 